\title{
Teaching Undergraduate Law Students in the 21st Century - Pedagogy in a Technological Era
}

\author{
By Michael Blissenden*
}

Teaching to law students in the 21st Century can be a daunting task for any law professor. Students come from different backgrounds, could be the first member of their family to go to university and bring with them varied experiences and exposure with modern technology, social media and the internet. Within this background, modern teaching pedagogy suggests that students need to be actively involved with their learning and that the learning and teaching environment needs to be student centred. This paper focusses on using the pedagogy of storytelling to build a bridge between teaching by law professors and learning for the modern law student in a technological era.

Keywords: Pedagogy, Technology, Active Learning

\section{Introduction}

Teaching undergraduate law students in the $21^{\text {st }}$ Century provides both challenges and opportunities. Such challenges include ensuring that students are actively engaged in their learning while they navigate an increasingly complex world that places high demands on student time. ${ }^{1}$ Opportunities also exist, especially with the expanding capacity of technology to assist with ensuring availability of an active student learning process in obtaining their undergraduate law degree. ${ }^{2}$ This article will examine how law professors have been utilizing a particular form of teaching pedagogy-storytelling - to stimulate engagement for law students. ${ }^{3}$ The article will then examine how advances in technology may facilitate learning for undergraduate law students. The article will then suggest a platform that law professors could comfortably utilize for the teaching pedagogy of storytelling in order to create an active learning experience within a digital environment.

\section{Storytelling in Legal Education}

The law is made up of many stories. ${ }^{4}$ Clients tell their lawyers the facts and circumstances of their situation, when in reality, this represents a story told from their point of view. Of course, others involved in the matter, be it civil or

\footnotetext{
${ }^{*}$ Deputy Dean of Operations \& International - School of Business, Associate Professor of Law Western Sydney University, Sydney, Australia.

${ }^{1}$ Kirley (2015) p. 221.

${ }^{2}$ Sadik (2008) p. 488.

${ }^{3}$ Capuano, Carmen et al (2014); Blissenden (2007) p..265.

${ }^{4}$ Moran (2015) p. 3.
} 
criminal, will also present facts to illustrate their side of the story. Judges also tell a story when deciding a case: they must weigh the facts, the law, and recount and apply that story in his or her judgment. ${ }^{1}$

It makes sense then that law students can be taught through the use of stories. In a common law jurisdiction, where there is an emphasis on case law and the application of precedent, it would be appropriate for students to look at such cases from a storytelling point of view. In a civil law jurisdiction with an emphasis on practice, procedure, and rules, students can investigate the stories behind the existence of these frameworks as part of their learning.

In the classroom environment, there are a number of ways the pedagogical basis of storytelling can be utilized. Professors can tell "war stories," thereby providing students insight into how the law functions, and how it can assist with student learning. ${ }^{2}$ This is a useful way to inform students about how the law operates, but it is essentially a teacher-led process. As such, it is a limiting approach in the 21st Century, where there has been a shift to student-centred learning.

A more student-cantered application of the storytelling methodology relates to the stories behind reported cases. ${ }^{3}$ The goal of this approach is to stimulate student interest in how the litigated case came before the courts. Students are required to investigate the factual background of the parties and research the information that each party believes is relevant to their position. Students are then required to present the results of their investigations to the class and explain how the parties' stories shaped the legal outcome and the application of precedent in the case. Storytelling can also be applicable to students studying in a civil law jurisdiction. One particular abstract concept or rule within the legal system can first be understood as representing a series of stories that led to the creation of the concept or rule. The students can then apply the concept or rule to the factual situation of a client in order to provide a solution to the client's legal problem.

Storytelling by students, themselves, can also be utilized as a learning mechanism. Students' experiences with the law can be shared with other members of the class in order to provide a platform to discuss the legal issues arising out of their stories. This process can provide an opportunity for students to express their thoughts and ideas in an informal environment, rather than in the formal environment of applying legal principles, which may be an intimidating experience.

\section{Students of the 21st Century}

Students of the $21^{\text {st }}$ Century come from a variety of backgrounds and have had various experiences before and during their law school studies. Many students come from disadvantaged backgrounds and may have had experiences

\footnotetext{
${ }^{1}$ Chestek (2013).

${ }^{2}$ Blissenden (2007) p. 262.

${ }^{3}$ Blissenden (2007) p. 267-269.
} 
and struggles with the law. These students can bring their stories into the classroom environment. For example, in the Australian classroom, students may have been victims of the indigenous stolen generation (children taken from their mothers), and may still be fighting for justice. In addition, law students today usually have to balance their law studies with work and family commitments. There is a good chance that these students have had exposure to the workings of the law and can bring those experiences into the classroom. For instance, students working part time can provide their insights and stories concerning employment-related matters, which may include basic work rights and responsibilities, trade union involvement, or contract law. These stories are invaluable in providing insight into the practical workings of the law.

\section{Technology and the $21^{\text {st }}$ Century Student}

As noted above, the $21^{\text {st }}$ century student comes from a range of different backgrounds and experiences. Another important trait of these students is the impact technology has had on their lives. ${ }^{1}$ Technology is introduced early in their lives through devices such as iPads, laptops, and mobile phones. Easy access to technology provides a way of life for the modern law student. ${ }^{2}$ There is no doubt that the modern law student brings the digital experience onto the university campus. The question is whether students bring the digital experience into the classroom environment. These two aspects of digital technology do not necessarily flow from one another: It cannot be said that students are able to move easily from utilizing digital technology for their modern lifestyle (such as texting, Facebooking, and communicating) to actually being able to utilize and use that same technology for educational purposes. $^{3}$

Educators, on the other hand, have considered there to be an easy fit between technology and its use for educational purposes. ${ }^{4}$ Under the guise of being innovative and responding to a student-cantered learning environment, educators have sought to justify the use of technology as the basis for learning and teaching law students in the $21^{\text {st }}$ Century. However, there is an error in this approach: technological advances cannot be a substitution for a sound learning and teaching pedagogy. ${ }^{5}$ The advances in technology should instead be utilized to supplement existing learning and teaching practices.

For instance, podcasts and online lectures should not replace face-to-face interaction between a professor and their students. ${ }^{6}$ Instead, podcasts and online lectures should provide flexibility for students who are attempting to balance study, work, and family commitments. Face time, in the form of face-

\footnotetext{
${ }^{1}$ Pistone (2014-15).

${ }^{2}$ Pistone (2014-15) p. 591; Newell (2015) p 18-19.

${ }^{3}$ Robin (2009).

${ }^{4}$ Robin (2009) p. 220.

${ }^{5}$ Levy (2015) p. 6-16

${ }^{6}$ Levy (2015) p. 44.
} 
to-face lectures and tutorials, provides the necessary link between the availability of online material and the facilitation of a learning environment. On the other hand, it would be a mistake to completely dismiss technology for educational purposes. It is clear that technology is a large part of everyday life, of which education is now an integral element. Consequently, it makes sense to link the two together. Technology provides a platform for communication and interaction, and to break down distance barriers. These exchanges are also important for successful educational environments. Communications - both oral and written - are critical to the learning experience. Interaction between a law professor and his or her students facilitates active learning, and any means of education across borders and distances should also be encouraged.

\section{Use of Technology and Storytelling}

Together, advances in technology and the established methodology of storytelling provide an ideal opportunity to enhance learning for modern day law students. The literature indicates that there has been a move towards this educational framework. ${ }^{1}$ Digital storytelling is now a recognized form of educational instruction that allows for students to construct stories through the use of modern computers' multimedia capabilities. Such an approach is highly relevant to student stories, as discussed above. ${ }^{2}$ This is especially the case where students create their own visual version of the story that they wish to convey to their classmates. However, it would be a mistake to assume that digital storytelling will provide the only means by which students may wish to convey their stories. ${ }^{3}$ Other digital technology, such as YouTube or uploaded videos to Facebook, may in fact provide a better platform for conveying the student's story. This also assumes that digital storytelling is part of an overall educational approach within the classroom. This requires the teacher to be flexible and willing to structure classroom time with the digital storytelling approach. Research also indicates that digital storytelling, by itself, does not facilitate a deep understanding of the concepts of a particular subject/unit. ${ }^{4}$ Consequently, there needs to be additional activities designed to ensure that a student obtains that deeper understanding.

What about the other storytelling approaches? In the case of "war stories," as retold by the teacher, can technology provide another dimension to enhance learning? The essence of war stories involve the telling of a story by the professor. In doing so, the story comes with a form of authenticity and standing. It may be that this form of storytelling, although teacher-led, is more appropriate in the storytelling framework without the need for technology. On the other hand, the professor could themselves utilize digital technologies to

\footnotetext{
${ }^{1}$ Lal, Donnelly \&Shin (2015) p. 58.

${ }^{2}$ Sadik (2008) p. 497.

${ }^{3}$ Sadik (2008) p. 493.

${ }^{4}$ Capuano, Gaeta et al (2015) p. 4-7.
} 
portray the essence of the war story to enhance student attention and focus. ${ }^{1}$ The ways as to how that may be portrayed are limited only by the imagination of the professor who is telling the war story.

There is a clear link between the availability and use of technology and the storytelling methodology of students recounting and portraying cases as stories. The World Wide Web provides a base of material for students to investigate, digest, and portray to classmates. ${ }^{2}$ The data bank of information surrounding the facts of a case can be distilled by students and retold as a story that outlines the parties' various arguments. Furthermore, the judgment of the court, as rendered by the presiding judge, can also be viewed as a story. Not only does the judge outline legal principles, he/she also decides which facts should be accepted in crafting the judgment, which is the conclusion of the story.

The availability of the Web now allows for students to discover an understanding of facts that in the past would have only been seen from the perspective of the judicial decision. ${ }^{3}$ From an Australian perspective, one very good example of how students can utilize the Web involves the 1966 High Court decision in Scott v. FCT. That case deals with a gift received by a solicitor from a client. The case examines the fine line between a true gift, which is not assessable as income in Australia, and a gift that is seen as being really connected with the provision of professional services as a solicitor, and that is assessable as income in Australia. The prescribed textbook for students only provided an extract of the case and not the full report of the judicial decision by the High Court. Of course, the full report was easily found on the Web through the Austlii website. The key was getting the students to read the full report, which then led them to further investigations surrounding the manner in which the High Court went about making their decision. More importantly, by reading the full report, there were a number of factual references that the High Court made that could then be explored through the vast resources of information on the Web. So although reading the full report is not, in itself, a massive leap (full reports are always preferable to the shortened versions), it was the context in which the full report was available to students. Students are used to using the internet, so it only takes a small step to get them engaged in utilizing the ${ }^{4}$ internet to locate the full report and then expand their research from there. For instance, there are usually hyperlinks within the online version of a judicial decision, allowing for easy access to further information.

A small number of students were asked to retell the story to the class. This required students to look behind the factual circumstances-not just the facts as stated in the case report. This required them to examine the background and explore some of the underlying reasons why the matter had been litigated in the first place. This then led the students to search through various databases of information to see why there may have been a basis for those reasons. In the particular case of Scott, there were specific facts that students were able to

\footnotetext{
${ }^{1}$ Kirley (2015) p. 221-222.

${ }^{2}$ Blissenden (2007) p. 266-271.

${ }^{3}$ Ibid.
} 
access via the Web. There was a history of the taxpayer being very generous. Gifts had been previously made, and one in particular could be investigated. There had been a substantial contribution to the community in relation to the establishment of a memorial to a submarine which sank during World War I. The taxpayer had a personal attachment to that historical event and felt compelled to contribute and give something back to the community. The history behind the establishment of this particular memorial could be accessed via the web, which added a new dimension to the factual circumstances as to why the taxpayer had made a monetary gift to their solicitor. Because of the digital element, this story could be retold to the class, allowing them to realize why the High Court subsequently found that the gift of $\$ 10,000$ to the solicitor should be seen as a true gift, and not assessable as income.

All students were also able to access the relevant Web page relating to the sunken submarine, making the facts of the case being studied even more realistic. The Web page is http://www.parracity.nsw.gov.au/play/sports_and recreation/parks_and_reserves2/k13_submarine_memorial_park. The web page information provided the necessary link with the taxpayer in Scotts case and illustrated the record of the taxpayer being a generous person and the fact that it was unsurprising that the gift of money to the solicitor was indeed just a gift. All students were then able to visualise how the story and the resulting litigation came about and were able to realize that the case was not just about legal principles. This is not to dismiss the importance of legal principle, but it illustrates the need for students to understand the underlying basis for how a case came before the courts for determination.

\section{Lessons Learned-Interplay Between Technology and Storytelling}

The above discussion highlights the potential for technology to play a role in the learning environment for modern law students. However, one key aspect to note is that technology is, of itself, not the answer. ${ }^{1}$ It is a platform through which learning and teaching in a student-cantered environment may be enhanced. Mere access to technology does not equate with an enhanced learning environment. Student access to technology can be a distraction rather than an enhancement. Student attention may be distracted and the learning environment is in fact hindered. It is the context of how the technology can be used and why the technology is being used that is important.

As demonstrated by established storytelling methodology, students can use technology to support their learning. It is critical to note that the interplay between the uses of storytelling is entrenched within the context of the classroom environment. There is still a need for in class face-to-face time to ensure that the uses of technology are interwoven into the learning practices. The use of technology for educational purposes is premised on the fact that the learning environment should be student-cantered. ${ }^{2}$ This means that students

\footnotetext{
${ }^{1}$ Levy (2015) p. 66.

${ }^{2}$ Pistone (2015) p. 597.
} 
should be actively engaged with their learning. In this context, being engaged means using technology for educationally-sound outcomes. Again, this would be more appropriate within a classroom setting. Student-cantered learning does not involve accessing online materials at leisure and learning off campus. There needs to be an understanding that online material is only part of an overall learning environment, which also means it must be actively engaged within a classroom context. ${ }^{1}$

The student retelling of the story in the Scott case, as discussed above, is a good example of how the use of technology can work in combination with classroom face-to-face interaction. Students locate, distil, and organize material from the Web outside the classroom and then bring this information into the classroom to present and engage with their professor and classmates. The availability of wireless internet access in most on campus classrooms adds to this process by allowing all students to actively engage with technology for learning purposes.

In order to teach students to think like lawyers, it is imperative for law professors to be aware of the tools that are available. ${ }^{2}$ Technological tools are one aspect of that approach and are not the only tools available. There is still the need for face-to-face instruction in order to facilitate the opportunity to engage with and deepen the learning experience for students.

The answer is that law professors need to be aware that technology can be a way to actively engage students, as shown with the storytelling methodology. It is also necessary for law professors to actively involve themselves in finding the most appropriate way to deepen student learning. This may require additional ways to reinforce the learning experience-possibly through a structured exercise in class, a formal lecture, or even by utilizing an oldfashioned method: textbooks.

This last aspect is particularly important. Technology will not replace the need for law professors to provide their input in the learning and teaching process through a variety of ways. The key is for law professors to be aware of the flexibility that technology provides to the learning experience, and that technology is a way of social and educational interaction for $21^{\text {st }}$ Century law students. There is still a need for law professors to engage their students and not think that technology is the only answer.

Technology has provided opportunities for both students and law professors to enhance the learning and teaching environment. Technological tools need to be embraced but are neither the answer nor the only way to teach our modern law students going forward.

\section{References}

Blissenden, M.W. 2007. 'Using Storytelling as a Teaching Model in a Law School: The Experience in an Australian Context', 41:3 The Law Teacher 260-74.

\footnotetext{
${ }^{1}$ Pistone (2015) p. 598.

${ }^{2}$ Levy (2015) p. 5.
} 
Capuano, N. \& D.M. Carmen, et al. 2014. 'A Storytelling Learning Model for Legal Education,' Paper presented at International Conference e-Learning.

Capuano, N., Gaeta, A., Fratesi, E., \& G. Mangione 2015. 'An Adaptive e-Learning System Based on Storytelling for Civil Mediation,' IADIS International Journal on E-Learning.

Chestek, K. 2013. 'Competing Stories: A Case Study of the Role of Narrative Reasoning in Judicial Decisions, ' Revista Forumul Judecatorilor 2:31-62.

Kirley, E.A. 2015. 'Are We Ethically Bound to Use Student Engagement Technologies for Teaching Law?' The Law Teacher 49:219-41.

Lal, S., Donnelly, C., \& Shin, J. 2015. 'Digital Storytelling: An Innovative Tool for Practice, Education, and Research, ' Occupational Therapy in Health Care 29:5462.

Levy, J. 2015. 'Teaching the Digital Caveman: Rethinking the Use of Classroom Technology in Law School,' 1-77.

Moran, J. 2015. 'Families, Law, and Literature: The Story of a Course on Storytelling,' University of San Francisco Law Review 49:1-56.

Newell, L. 2015. 'Redefining Attention (and Revamping the Legal Profession?) for the Digital Generation' 15 Nevada Law Journal 1-60.

Pistone, M. 2014-15. 'Law Schools and Technology: Where We are and Where We are Heading,' Journal of Legal Education 64:586-603.

Robin, B. 2009. 'Digital Storytelling: A Powerful Technology Tool for the $21^{\text {st }}$ Century Classroom,' Theory into Practice 47:220-28.

Sadik, A. 2008. 'Digital Storytelling: A Meaningful Technology-Integrated Approach for Engaged Student Learning, ' Educational Technology, Research and Development 56: 487-506. 